IIIIIIIIIIIIIIIIIIIIIIIIIIII

報

文

|IIIIIIIIIIIIIIIIIIIIIIIIIIII

\title{
殺菌剤ベノミル水和剤の樹幹注入によるナラ類集団枯損被害に 対する予防効果
}

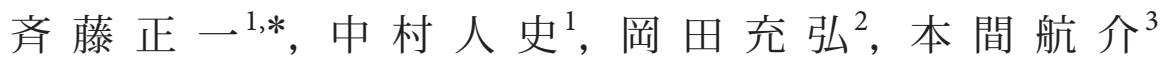 \\ ${ }^{1}$ 山形県森林研究研修センター \\ 2 長野県林業総合センター \\ 3 新潟大学農学部附属フィールド科学教育研究センター \\ （2013年1月 19日受付，2013年12月 19日受理）
}

\section{Preventive effect of trunk injection of benomyl wettable powder on mass mortality of oak trees}

\author{
Shoichi Saito, ${ }^{1}$ Hitoshi Nakamura, ${ }^{1}$ Mitsuhiro Okada ${ }^{2}$ and Kosuke Honma ${ }^{3}$ \\ ${ }^{1}$ Yamagata Prefectural Forest Research and Instruction Center, 2707 Sagae-Hei, Sagae, Yamagata 991-0041, Japan \\ ${ }^{2}$ Nagano Prefecture Forestry Research Center, 5739 Kataoka, Shiojiri, Nagano 399-0711, Japan \\ ${ }^{3}$ Field Center for Sustainable Agriculture and Forestry, Niigata University, 94-2 Koda, Sado, Niigata 950-2181, Japan
}

\begin{abstract}
The preventive effect of benomyl on oak wilt disease was evaluated in Yamagata, Nagano and Niigata prefectures in Japan from 2004 to 2008. In Yamagata, a dilution of benomyl wettable powder in water (a.i benomyl $2 \mu \mathrm{g} / \mathrm{mL}$ ) was directly injected into the trunks of non-damaged healthy Japanese oak trees in June. A month later, Japanese oak wilt fungus Raffaelea quercivora was inplanted into the trunks. Twelve weeks later, all of the benomyl-inoculated trees remained alive, and the fungus was recovered from a few of them. Most of the non-injected trees died, and the fungus was reisolated with very high frequency. Benomyl wettable powder diluted with water by five hundred numbers was injected into living trees during a total of fourteen tests on eight fields in three prefectures. As for mortality rate, a clear and significant difference between the examination section using benomyl and the control was not found on Fisher's Exacts test. However, the mortality rates of all the examination districts where benomyl was used were lower than the control areas up to three years after the injections. Therefore, trunk injections of benomyl suggested a higher preventive effect against Raffaelea quercivora. () Pesticide Science Society of Japan

Keywords: oak mass mortality, Raffaelea quercivora, benomyl wettable powder, trunk injection.
\end{abstract}

\section{緒 \\ $\overline{\overline{\bar{一}}}$ \\ ブナ科樹木萎调病によるナラ類の集団枯損被害（以下，ナ ラ枯れ）は拡大が続いており，その防除方法の開発は緊急を}

\footnotetext{
* = 991-0041山形県寒河江市寒河江丙 2707

E-mail: saitoshoi@pref.yamagata.jp

(c) 日本農薬学会
}

要している. 本病はカシノナガキクイムシ（Platypus quercivorus, 以下カシナガ）がブナ科萎调病菌（Raffaelea quercivora, 以下ナラ菌）を媒介することで発生する ${ }^{1,2)}$. ナラ枯 れによる被害は, 2005年までは最北端の山形県から最西端 の島根県までの日本海側を中心に拡大し, その後も2006年 には秋田県および愛知県, 2007年は山口県, 2008年に広島 県で新たに確認され，2010年には青森県, 岩手県および静 岡県で発生しており1990年以降も被害終息の目処は立って 
いない ${ }^{3)}$. 本病は落葉ナラ類（ミズナラ, コナラ等）や常緑 シイ・カシ類（スダジイ, ウバメガシ等）に被害を与えてお り, 中でもミズナラでは枯死率が高い4). 東北地方では山形 県を主として6県すべてで被害が発生しており，ミズナラの 現存量の多さを反映して被害量も甚大である. また, 海岸林 内にはミズナラ・コナラ・カシワが点在し, それらが感染の 経路となるため, 被害の北進スピードは極めて速い5).

被害木の処理方法として, 被害木の樹幹下部に多数の注入 孔をあけてカーバム液剤（成分：カーバムアンモニウム塩 40\%）を注入し殺虫する方法が開発・実用化された ${ }^{6,7)}$. ま た，枯死木内のカシナガの完全殺虫を目指した，メチルイソ チオシアネート液化炭酸製剤（成分：メチルイソチオシア ネート 20\%), およびカーバム液剤によって伐倒丸太や伐根 をくん蒸処理する方法も開発されている ${ }^{8,9)}$. 一方, 本被害 に対する予防方法として，未被害木樹幹をシートで被覆する 方法 ${ }^{10)}$, 粘着剂等を散布してカシナガの穿入を物理的に妨 害する方法 ${ }^{11-14)}$, フェニトロチオン乳剂（成分：フェニト ロチオン $80 \%$ ） 50倍液を散布する方法 ${ }^{15)}$ が開発され, 段階 的に実用化が進められているが, さらに省力的で効果が確実 な方法の開発が求められている.

多数のカシナガが穿入時にナラ立木樹幹内にナラ菌を持ち 込むことで枯死が起こることから，ナラ類立木辺材における ナラ菌の増殖を抑制すれば被害を予防できると考えられる. 斉藤ら ${ }^{16)}$ はMSY-104（主成分 Diiodomethyl-p-tolylsulfone $5 \mathrm{ppm}$, モーリー研究所, 以下MSY-104）の樹幹注入によ り, 樹幹内でのナラ菌の増殖抑制の効果, およびナラ類の枯 死を防止する効果を報告した。 しかし，MSY-104の注入が 不完全で効果が不十分の場合には, ナラ枯れが発生する可能 性があること，コスト面などで農薬登録が難しいことなどか ら, 実用化が困難であった。したがって, より効果的かつ殺 菌剂としての農薬登録拡大が可能な農薬による樹幹注入処理 を検討する必要があった，殺菌剂のべノミル水和剂（有効成 分：ベノミル $50 \%$, 住友化学(株製) は市販されており入手が 容易である上，ナラ菌のような糸状菌に対する殺菌効果があ るため, 殺菌剤として農薬登録することが可能であると考え た、そこで, 筆者らはべノミル水和剤希釈液をミズナラとコ ナラの樹幹に注入することによる枯死被害予防効果について 検討したので報告する。

\section{実 験 方 法}

\section{1. ナラ菌接種によるベノミル剂樹幹注入のナラ枯れ防止 効果の試験}

本研究では，ベノミルの製剤として水和剤を使用した。殺 菌剂ベノミル水和剂を 500 倍水希釈液（以下， ベノミル500 倍液）として試験に供した。 ベノミル500倍液のナラ菌に対 する効果を確認するため, 健全なミズナラにべノミル 500 倍 液を樹幹注入した後にナラ菌を接種して萎凋および枯死の
発生経過を観察した。試験場所は，ナラ枯れ被害がない山形 県森林研究研修センターの約 50 年生のミズナラ試験林（山 形県西村山郡西川町沼山）とした。試験には, ベノミル500 倍希釈液, および対照試薬としてナラ菌の増殖抑制が確認 されている前出の MSY-104 (Diiodomethyl-p-tolylsulfone $5 \mathrm{ppm}$ ）を用いた。試験区は，ベノミル500倍液やMSY-104 を健全なミズナラへ事前に樹幹注入した後, 殺菌剂の樹幹 内での分散を考えて注入 2 週後にナラ菌を接種する「べノ ミル区」,「MSY-104区」および，「対照区」を設定し，健全 なミズナラ立木（胸高直径 $18 〜 30 \mathrm{~cm}$ ）を供試した。供試 樹には, 試験地で観察に適した立木を選び, ベノミル区は 3本, MSY-104区および対照区は5本を供試した。べノミル

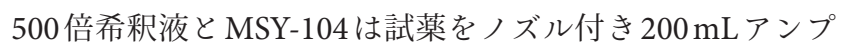
ル（ファイザー製グリーンガードエイトの使用済み材料を 中性洗剂と水道水で洗浄して使用）に充填し, 供試木への 注入は, 松くい虫被害防止用薬剂の樹幹注入剂の施用法 ${ }^{17)}$ を参考にしたMSY-104の注入量を採用して ${ }^{16)}$, 胸高直径 $20 \mathrm{~cm}$ 未満の木で $800 \sim 1,000 \mathrm{~mL}, 20 \sim 30 \mathrm{~cm}$ の木で 1,000 $1,200 \mathrm{~mL}$ とた。試薬を充填したアンプルは, 樹幹の地上 高 $50 \mathrm{~cm}$ の位置にノズルの口径に合わせて，7～8 $\mathrm{mm}$ の注入 孔を斜め 45 度に 25 ～ $30 \mathrm{~mm}$ の深さで開けて自然圧で注入し た. 山形県庄内地方でのカシナガの平均初発日は 6 月 26 日 であるので ${ }^{18)}$, これら試薬の樹幹注入はカシナガの初発日 前の 2004年6月 4 日とし, ナラ菌の接種は, 試験地近傍の被 害地でカシナガの大量発生が盛んに起こる2004年7月7日と した。接種試験に用いたナラ菌は, 山形県鶴岡市大字西荒屋 のナラ枯れ被害林において2003年夏に枯死した立木より採 取し, 筆者が単離した菌株を森林総合研究所東北支所の窪野 高徳博士にナラ菌であるか同定いただいた。この単離したナ ラ菌（保有菌株：YA0301）をコメヌカとフスマを添加した オガ粉の混合培地（重量比 $1: 1: 1$ ) を用い, $25^{\circ} \mathrm{C}$ で 18 日間 静置培養した ${ }^{19)}$. ナラ菌の接種試験は, 斉藤ら ${ }^{19)}$ の方法を 参考に行った. 地上 $1.0 \mathrm{~m}$ の部位に樹幹を 1 周する列状の小

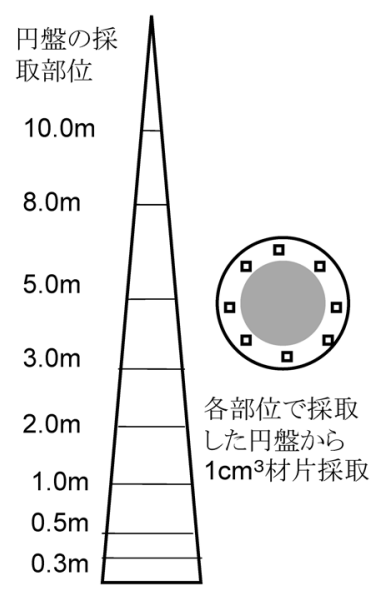

Fig. 1. Position of gathering disks and fragments. 
孔（径 $8 \mathrm{~mm}$, 深さ $25 \mathrm{~mm}$, 間隔 $30 \mathrm{~mm}$ ）を上下に $50 \mathrm{~mm}$ 間 隔で6列あけて接種孔とし，ナラ菌を培養した混合培地を接 種孔 1 孔あたり約 $1 \mathrm{~g}$ 挿入した. 各供試木の接種孔数は 100 孔程度である。供試木の観察は, 接種後 4 週までは毎週, 以 後 12 週までは 4 週おきに行い, 正常（見かけ上，樹幹の葉 が緑色の状態) ・異常（樹冠の葉が萎调し, 緑葉が褐変し始 めた状況）・枯死（樹冠の葉全体が褐色になった状態）に区 分して記録した。 また, ナラ菌の樹幹内の動態については,

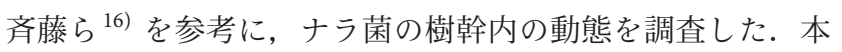
調査は 12 週目にべノミル区と MSY-104区から枯死しなかっ た供試木および対照区から枯死木を伐倒し，地上 $0.3,0.5$, 1.0, 2.0,3.0, 5.0, 8.0, $10.0 \mathrm{~m}$ より厚さ 5〜 $10 \mathrm{~cm}$ の円盤を採取 して, 辺材から $1 \mathrm{~cm}$ 四方の材片を各 8 個採取し（Fig. 1), $0.5 \%$ 次亜塩素酸ナトリウム溶液で 5 分間表面殺菌後, 滅菌 水で 3 回洗浄し, $20^{\circ} \mathrm{C}$ にて 2 週間 PDA培地上で培養して分 離された菌株を窪野高徳博士に同定いただき，ナラ菌の分離 率を確認した。なお，この試験結果の一部は斉藤ら ${ }^{16)}$ を引 用した。

\section{2. ナラ枯れ被害林におけるベノミル剂樹幹注入のナラ枯 れ予防効果の調査}

ベノミル希勫液のナラ類への樹幹注入によるナラ枯れ予 防の実証試験は, ナラ枯れ被害が発生している山形県・長野 県・新潟県で実施した。各試験地と試験地の設置年および概 況はTable 1 のおりである.

試験実施年と実施県・試験地数は, 2004 年 1 県 1 試験地, 2005 年 1 県 1 試験地, 2006 年 2 県 4 試験地, 2007 年 3 県 5 試 験地, 2008 年 2 県 3 試験地であり, 4 力年で 3 県 8 試験地（の へ14の試験）において実証試験を実施した。試験地は, 試
験区の供試木にカシナガが穿入することが予想される場所で 実施することとし, 山形県でのこれまでの調査で得た結果で 被害区分をした参考にして ${ }^{21)}$ 微害から激害（1試験地のみ次 年度被害が発生しそうな未被害）のミズナラ・コナラ林また はコナラ林とし, 未被害のナラ類立木を供試木として選び, 所定の薬液の注入を各地におけるカシナガの羽化脱出前の 5〜6月に実施した.

使用した試薬は, 前述のべノミル 500 倍液, 対照試薬であ

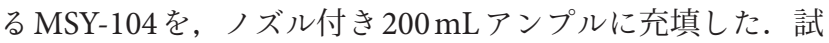
薬の注入量は, 前述のとおり胸高直径から算出して胸高直径 $20 \mathrm{~cm}$ 未満の木で 800〜 1,000 mL, 20〜 30 cmの木で 1,000 $1,200 \mathrm{~mL}, 30 \sim 40 \mathrm{~cm}$ の木で 1,400〜 1,600 mL, 40〜 $60 \mathrm{~cm}$ の木 で 2,200〜 5,600 mL とした. 薬剤注入孔は, 樹幹下部の地上 20〜 $50 \mathrm{~cm}$ に径 7〜 $8 \mathrm{~mm}$ の注入孔を斜め 45 度に $25 \sim 30 \mathrm{~mm}$ の深さで開けてアンプルを自然圧で注入した。

試験区は, ベノミル水和剂 500 倍液を処理したべノミル 区，無処理区および対照薬剤のMSY-104区（2005年および 2006年)とした.

供試木は各試験地の各試験区において 3 本以上とし, 未被 害のミズナラかコナラの生立木を用いた. 全試験地を通じた 供試木の平均胸高直径は $17.8 \sim 50.4 \mathrm{~cm}$, 平均樹高は $13.5 \sim$ $21.9 \mathrm{~m}$ で，ミズナラ・コナラの二次林における林齢 $40 \sim 60$ 年生の立木としてはほぼ平均的なサイズであった ${ }^{3)}$.

また, 試薬の樹幹注入では, 試薬の注入状況を確認するた めに, 注入成功率を調査した. 試液の注入は自然圧を用いて おり, 注入状況と天候が試験地によって一様でないため, 試 液の注入状況は，7日後までにアンプルを回収しその際にア ンプル内の試液の残存量を計って差引き, 注入量との比を注 入成功率とした。

Table 1. Conspectus of fields

\begin{tabular}{|c|c|c|c|c|}
\hline 注入処理年月日 & 県市町村 & 試験地 & 被害区分 & 林況 \\
\hline 2004.6.19 21 & 山形県鶴岡市 & 桜ヶ丘 & 激害 & 50 年生ミズナラ・コナラ林 \\
\hline 2005.6.17 20 & 山形県西川町 & 弓張平 & 微害 & 55年生ミズナラ林 \\
\hline 2006.6.1 4 & 山形県小国町 & 玉川 & 微～激害 & 60 年生ミズナラ・コナラ林 \\
\hline 2006.6.1 $\sim 4$ & "l & 大宮 & 微〜中害 & 60 年生ミズナラ・コナラ林 \\
\hline 2006.6.1 4 & "1 & 市野沢 & 中害 & 70年生コナラ林 \\
\hline $2006.5 .27 \sim 6.2$ & 新潟県佐渡市 & キセン城 & 微害 & 40 年生ミズナラ・コナラ林 \\
\hline 2007.5.24 30 & 山形県小国町 & 玉川 & 微～激害 & 60 年生ミズナラ・コナラ林 \\
\hline 2007.5.24 30 & "I & 大宮 & 微〜中害 & 60 年生ミズナラ・コナラ林 \\
\hline 2007.5.21 27 & $\prime \prime$ & 金目 & 微害 & 60 年生コナラ林 \\
\hline $2007.6 .4 \sim 12$ & 長野県飯山市 & 柄山 & 微害 & 40〜60年生ミズナラ林 \\
\hline $2007.6 .9 \sim 15$ & 新潟県佐渡市 & キセン城 & 微害 & 40 年生ミズナラ・コナラ林 \\
\hline $2008.5 .21 \sim 27$ & 山形県小国町 & 玉川 & 微～激害 & 60 年生ミズナラ・コナラ林 \\
\hline 2008.5.21 27 & " & 大宮 & 微〜中害 & 60 年生ミズナラ・コナラ林 \\
\hline 2008.6.7 9 & 新潟県佐渡市 & キセン城 & 微害 & 40 年生ミズナラ・コナラ林 \\
\hline
\end{tabular}


Table 2. Conspectus of treatment of each test

\begin{tabular}{|c|c|c|c|c|c|c|c|c|}
\hline \multirow[b]{2}{*}{ 注入年度 } & \multirow[b]{2}{*}{ 県名 } & \multirow[b]{2}{*}{ 試験地 } & \multicolumn{2}{|c|}{ ベノミル区 } & \multicolumn{2}{|c|}{ 無処理区 } & \multicolumn{2}{|c|}{ MSY-104区 } \\
\hline & & & 供試本数 & $\begin{array}{c}\text { 平均胸高直径 } \\
(\mathrm{cm})\end{array}$ & 供試本数 & $\begin{array}{c}\text { 平均胸高直径 } \\
(\mathrm{cm})\end{array}$ & 供試本数 & $\begin{array}{c}\text { 平均胸高直径 } \\
(\mathrm{cm})\end{array}$ \\
\hline 2004 & 山形県 & 桜ヶ丘 & 13 & 33.0 & 18 & 30.4 & & \\
\hline 2005 & 山形県 & 弓張平 & 14 & 23.3 & 14 & 21.4 & 13 & 17.8 \\
\hline \multirow[t]{4}{*}{2006} & 山形県 & 玉川 & 13 & 29.6 & 14 & 31.9 & 12 & 33.0 \\
\hline & $\prime \prime$ & 大宮 & 9 & 31.4 & 19 & 33.6 & 8 & 28.4 \\
\hline & "I & 市野沢 & 3 & 47.5 & 3 & 36.2 & 3 & 50.8 \\
\hline & 新潟県 & キセン城 & 18 & 35.1 & 10 & 37.6 & 14 & 30.4 \\
\hline \multirow[t]{5}{*}{2007} & 山形県 & 玉川 & 7 & 31.4 & 14 & 33.1 & & \\
\hline & $" 1$ & 大宮 & 6 & 31.4 & 3 & 33.6 & & \\
\hline & "I & 金目 & 11 & 26.0 & 3 & 25.7 & & \\
\hline & 長野県 & 柄山 & 20 & 33.2 & 10 & 29.8 & & \\
\hline & 新潟県 & キセン城 & 4 & 50.4 & 10 & 37.4 & & \\
\hline \multirow[t]{3}{*}{2008} & 山形県 & 玉川 & 5 & 29.0 & 5 & 27.8 & & \\
\hline & "I & 大宮 & 12 & 27.3 & 10 & 23.3 & & \\
\hline & 新潟県 & キセン城 & 3 & 44.2 & 9 & 37.6 & & \\
\hline
\end{tabular}

Concentration of chemical Benomyl plot Benomyl wettable powder (a.i. $2 \mu \mathrm{g} / \mathrm{mL}$ ). MSY-104 plot Diiodomethyl-p-tolylsulfone $5 \mathrm{ppm}$.

Table 3. Control of wilting symptom by each chemical treating test

\begin{tabular}{|c|c|c|c|c|c|c|c|c|}
\hline \multirow{2}{*}{ 試験区 } & \multirow{2}{*}{ 供試本数 } & \multirow{2}{*}{ 様態 } & \multicolumn{6}{|c|}{ 本数 } \\
\hline & & & 1 週後 & 2週後 & 3週後 & 4週後 & 8 週後 & 12 週後 \\
\hline \multirow[t]{3}{*}{ ベノミル } & 3 & 正常 & 3 & 3 & 3 & 3 & 3 & 3 \\
\hline & & 異常 & 0 & 0 & 0 & 0 & 0 & 0 \\
\hline & & 枯死 & 0 & 0 & 0 & 0 & 0 & 0 \\
\hline \multirow[t]{3}{*}{ MSY-104 } & 5 & 正常 & 5 & 5 & 5 & 5 & 5 & 5 \\
\hline & & 異常 & 0 & 0 & 0 & 0 & 0 & 0 \\
\hline & & 枯死 & 0 & 0 & 0 & 0 & 0 & 0 \\
\hline \multirow[t]{3}{*}{ 無処理 } & 5 & 正常 & 5 & 3 & 1 & 1 & 1 & 1 \\
\hline & & 異常 & 0 & 2 & 2 & 0 & 0 & 0 \\
\hline & & 枯死 & 0 & 0 & 2 & 4 & 4 & 4 \\
\hline
\end{tabular}

Experimental site Nishikawa town Yamagata prefecture (Same site Table 2).

Concentration of chemical Benomyl plot Benomyl wettable powder (a.i. $2 \mu \mathrm{g} / \mathrm{mL})$. MSY-104 plot Diiodomethyl- $p$-tolylsulfone $5 \mathrm{ppm}$.

Process of test Trunk injection 2004.6.4, Inoculation of Raffaelea quercivora 2004.7.7.

試薬の樹幹注入による枯死防止効果調査は, 枯死に関係 する外見上の様態が安定する9月末に実施し，生存（見かけ 上，樹幹の葉が褐色になっておらず，生きた冬芽を形成して いる状態)・枯死（樹冠の葉全体が褐色になっており，冬芽 の内部が褐変している状態）に区分した。同時に供試木樹幹 の地上 $0 \sim 4 \mathrm{~m}$ までのカシナガの穿孔数を数えた. 予防試験 を行う上では, カシナガの穿入があって初めて効果の確認が
可能になる. 市原ら ${ }^{21)}$ は, カシナガの穿入数とミズナラの 萎调の関係を明らかにしており, 降雨量の影響はあるもの の穿大数 10 数個で枯死の発生を確認している. したがって, カシナガの穿入孔が 10 個以上あれば，予防効果を確認でき る供試木と考えられた. 以上のナラ枯れ予防調查は, 各試験 地に扔いて毎年実施した。 
Table 4. Segregation-frequency of Raffaelea quercivora of fragments on gathered disks from trees of inoculating wilt fungus

\begin{tabular}{|c|c|c|c|c|c|c|c|c|c|c|c|c|c|c|}
\hline \multirow{3}{*}{$\begin{array}{c}\text { 試験区 } \\
\text { 供試木No. } \\
\text { 様態 }\end{array}$} & \multirow[b]{3}{*}{ 処理 } & \multicolumn{3}{|c|}{ ベノミル区 } & \multicolumn{5}{|c|}{ MSY-104区 } & \multicolumn{5}{|c|}{ 無処理区 } \\
\hline & & 1 & 2 & 3 & 1 & 2 & 3 & 4 & 5 & 1 & 2 & 3 & 4 & 5 \\
\hline & & 正常 & 正常 & 正常 & 正常 & 正常 & 正常 & 正常 & 正常 & 枯死 & 枯死 & 正常 & 枯死 & 枯死 \\
\hline \multicolumn{15}{|l|}{ 地上高 (m) } \\
\hline 10.0 & & 0 & 0 & 0 & 0 & 0 & 0 & 0 & 0 & 37.5 & 50.0 & 25.0 & 75.0 & 37.5 \\
\hline 8.0 & & 0 & 0 & 0 & 0 & 0 & 0 & 0 & 0 & 62.5 & 62.5 & 37.5 & 50.0 & 62.5 \\
\hline 5.0 & & 0 & 0 & 0 & 0 & 0 & 0 & 0 & 0 & 87.5 & 62.5 & 62.5 & 62.5 & 62.5 \\
\hline 3.0 & & 0 & 0 & 0 & 0 & 0 & 0 & 0 & 0 & 75.0 & 75.0 & 50.0 & 75.0 & 75.0 \\
\hline 2.0 & & 0 & 0 & 0 & 0 & 0 & 0 & 0 & 0 & 100 & 62.5 & 75.0 & 100 & 100 \\
\hline 1.0 & 菌接種 & 25.0 & 12.5 & 0 & 12.5 & 12.5 & 12.5 & 0 & 12.5 & 87.5 & 100 & 75.0 & 100 & 100 \\
\hline 0.8 & & 0 & 0 & 0 & 0 & 0 & 0 & 0 & 0 & 87.5 & 87.5 & 75.0 & 100 & 100 \\
\hline 0.5 & 試薬注入 & 0 & 0 & 0 & 0 & 0 & 0 & 0 & 0 & 87.5 & 87.5 & 87.5 & 75.0 & 75.0 \\
\hline 0.3 & & 0 & 0 & 0 & 0 & 0 & 0 & 0 & 0 & 87.5 & 75.0 & 50.0 & 75.0 & 87.5 \\
\hline
\end{tabular}

Numbers of table Rate of segregation of Raffaelea quercivora from 8 fragments

Experimental site Nishikawa town Yamagata prefecture (Same site Table 2).

Concentration of chemical Benomyl plot Benomyl wettable powder (a.i. $2 \mu \mathrm{g} / \mathrm{mL}$ ).

MSY-104 plot Diiodomethyl-p-tolylsulfone $5 \mathrm{ppm}$.

Process of test Trunk injection 2004.6.4, Inoculation of Raffaelea quercivora 2004.7.7, Cutting.Segregation of fungus 2004.9.29, Examination of fungus 2004.10.13.

\section{結 果}

\section{1. ナラ菌接種によるベノミル剤樹幹注入のナラ枯れ防止 効果}

Table 3 に試薬の樹幹注入後におけるナラ菌接種試験の結 果を示す.

ベノミル区MSY-104区の供試木では，枯死や異常は8月 末までの 12 週間認められなかった。しかし，ナラ菌のみを 接種した供試木 5 本の内 4 本は接種 8 週後に枯死した。 また 接種 12 週後のナラ菌の分離率を調査したところ, ベノミル 区とMSY-104区では，ナラ菌接種孔の部位のみで分離され たがその他の部位では分離されなかった。これに対して，無 処理区ではすべての立木の樹幹全体からナラ菌が広範囲に分 離された（Table 4).

\section{2. ナラ枯れ被害林におけるベノミル剤樹幹注入のナラ枯 れ予防効果}

Table 5に心゙ノミル区の全試験地における供試木138本の 注入成功率別の枯死本数と枯死率について示した．供試木 138 本において，注入成功率は 80 100\%で 98本であり枯死 本数はわずか 1 本（枯死率 $1 \%$ ), 成功率 60 ～ $80 \%$ は 36 本で 枯死本数 4 本（枯死率 $11 \%$ ), 成功率 $40 \sim 60 \%$ では 3 本中す べてが枯死した（枯死率 100\%）。このように注入成功率が高 い場合は供試木の枯死率が極めて低いことが確認された。 なお，ベノミルの濃度について，500倍液と 250 倍液の樹
Table 5. Numbers of death-trees and mortality rate of success-rate of bemomyl

\begin{tabular}{cccc}
\hline 注入成功率 $(\%)$ & 注入供試本数 & 枯死本数 & 枯死率 $(\%)$ \\
\hline $80-100$ & 98 & 1 & 1.0 \\
$60-80$ & 36 & 4 & 11.1 \\
$40-60$ & 3 & 3 & 100.0 \\
$20-40$ & - & - & - \\
$0-20$ & - & - & - \\
\hline 計 & 138 & 8 & \\
\hline
\end{tabular}

Experimental site Yamagata, Nagano, Niigata Prefecture.

Concentration of chemical Benomyl plot Benomyl wettable powder (a.i. $2 \mu \mathrm{g} / \mathrm{mL})$.

Process of test Trunk injection 2004-2008. May-June. Research of death-trees 2004-2008. September.

幹注入で検討したが， 250 倍液は注入用アンプルのノズルの 先に試薬の残椬がつまり, 注入が困難となるため, 実用的な 希橎倍率ではないことがわかった。

3 年間にわたる供試木の経過を Table 6 に示した。いずれ の試験区の供試木も開始当年 9 月のカシナガの穿孔数が 10 個以上に達しており, ナラ枯れ予防効果を調査できると判断 した，したがって，試験区同士を単純に比較し，枯死率の低 いものに予防効果があったと考えた。

ナラ枯れ被害は, 1 林分で3年程度継続して発生するが3), 枯死率は，14の試験すべてでべノミル区が無処理区ょり 


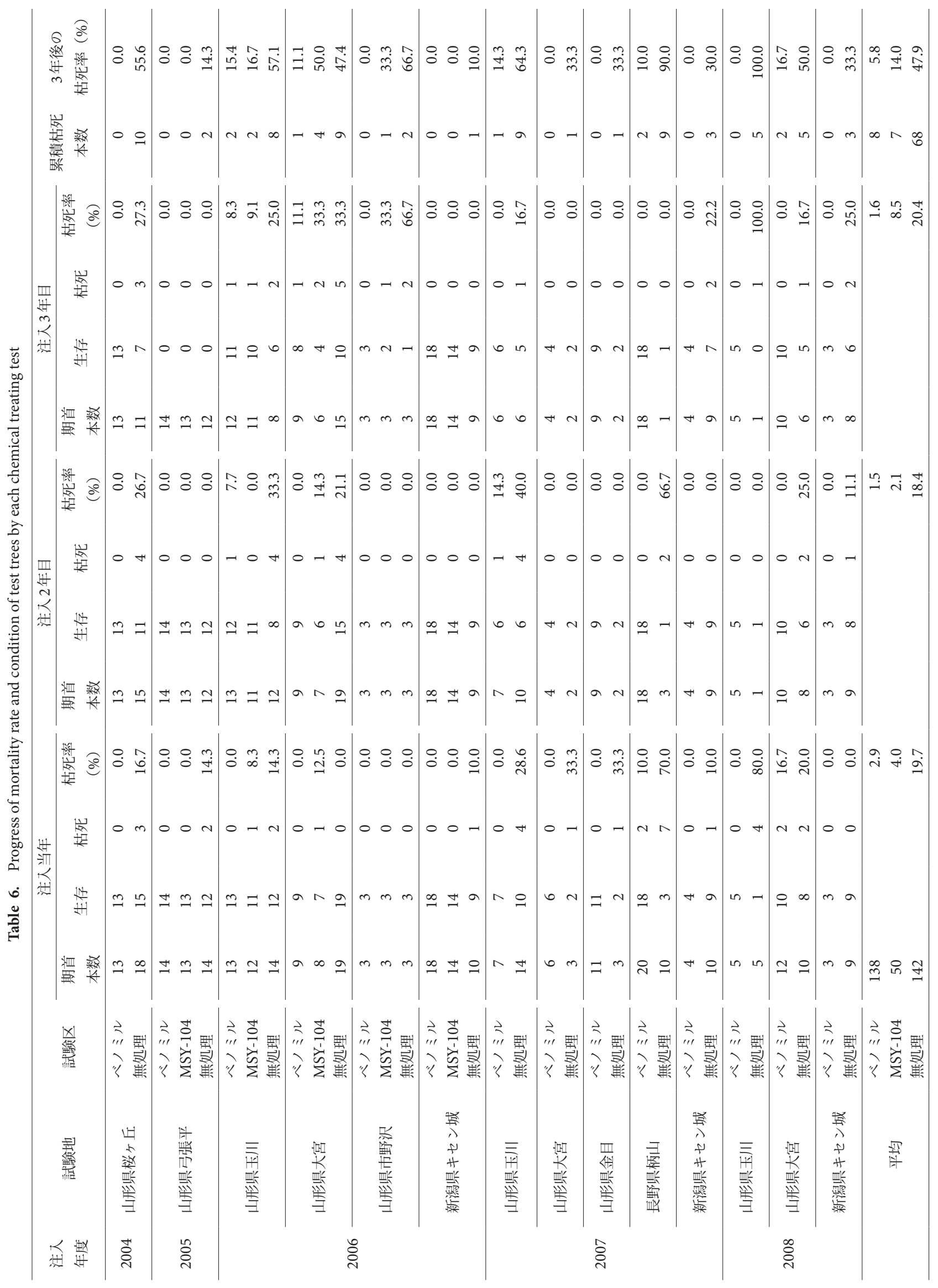


Table 7. Test of significant difference of control of mortality rate by treating benomyl

\begin{tabular}{|c|c|c|c|c|c|c|c|}
\hline \multirow{3}{*}{ 注入年度 } & \multirow{3}{*}{ 県名 } & \multirow{3}{*}{ 試験地 } & \multirow{3}{*}{ 試験区 } & \multirow{3}{*}{ 供試本数 } & \multirow{3}{*}{$\begin{array}{c}\text { 期末時の枯死率 } \\
\text { (\%) }\end{array}$} & \multicolumn{2}{|c|}{ Fisher の直接確率検定 } \\
\hline & & & & & & \multicolumn{2}{|c|}{ 片側 } \\
\hline & & & & & & $p$ 值 & 有意差 \\
\hline \multirow[t]{2}{*}{2004} & 山形 & 桜ヶ丘 & ベノミル区 & 13 & 0 & 0.0010 & $* *$ \\
\hline & & & 無処理区 & 18 & 56 & & \\
\hline \multirow[t]{2}{*}{2005} & 山形 & 弓張平 & ベノミル区 & 14 & 0 & 0.2407 & \\
\hline & & & 無処理区 & 14 & 14 & & \\
\hline \multirow[t]{8}{*}{2006} & 山形 & 玉川 & ベノミル区 & 13 & 15 & 0.0310 & $*$ \\
\hline & & & 無処理区 & 14 & 57 & & \\
\hline & "1 & 大宮 & ベノミル区 & 9 & 11 & 0.0704 & \\
\hline & & & 無処理区 & 19 & 47 & & \\
\hline & $\prime \prime$ & 市野沢 & ベノミル区 & 3 & 0 & 0.2000 & \\
\hline & & & 無処理区 & 3 & 67 & & \\
\hline & 新潟 & キセン城 & ベノミル区 & 18 & 0 & 0.3571 & \\
\hline & & & 無処理区 & 10 & 10 & & \\
\hline \multirow[t]{10}{*}{2007} & 山形 & 玉川 & ベノミル区 & 7 & 14 & 0.0426 & $*$ \\
\hline & & & 無処理区 & 14 & 64 & & \\
\hline & $\prime \prime$ & 大宮 & ベノミル区 & 6 & 0 & 0.3333 & \\
\hline & & & 無処理区 & 3 & 33 & & \\
\hline & " & 金目 & ベノミル区 & 11 & 0 & 0.2143 & \\
\hline & & & 無処理区 & 3 & 33 & & \\
\hline & 長野 & 柄山 & ベノミル区 & 20 & 10 & 0.00004 & $* *$ \\
\hline & & & 無処理区 & 10 & 90 & & \\
\hline & 新潟 & キセン城 & ベノミル区 & 4 & 0 & 0.3818 & \\
\hline & & & 無処理区 & 10 & 30 & & \\
\hline \multirow[t]{6}{*}{2008} & 山形 & 玉川 & ベノミル区 & 5 & 0 & 0.0040 & $* *$ \\
\hline & & & 無処理区 & 5 & 100 & & \\
\hline & " & 大宮 & ベノミル区 & 12 & 17 & 0.1130 & \\
\hline & & & 無処理区 & 10 & 50 & & \\
\hline & 新潟 & キセン城 & ベノミル区 & 3 & 0 & 0.3818 & \\
\hline & & & 無処理区 & 9 & 33 & & \\
\hline
\end{tabular}

Significance level $* 5 \%, * * 1 \%$.

注入当年から 3 年目まで低くなった。また，べノミル区と MSY-104区については，2006年の大宮試験地の注入当年で

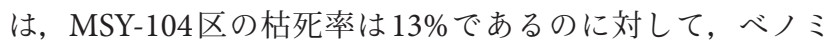
ル区と無処理区は0\%であった。さらに，2006年の玉川試 験地の注入当年では無処理区で $14 \%$ の枯死率であったが, MSY104区では $8 \%$ と高いものの, ベノミル区は $0 \%$ あり， ベノミル区は枯死率が低い結果であった.

各試験地の枯死率を Fisherの直接確率で片側検定したとこ ろ，14の試験中，5試験においてべノミル区で有意に枯死率 が小さかった．また，べノミル区とMSY-104区の両側検定
で有意差は認められなかった（Table 7).

\section{考察}

殺菌剂ベノミル水和剂の水希釈液の樹幹注入がナラ枯被 害の予防に有効かどうかを検討した。 ベノミル500倍液を事 前に樹幹注入したミズナラの未被害木へのナラ菌の接種試験 の結果, ベノミル500 倍液を所定量樹幹注入した立木は枯死 せず，樹幹内でのナラ菌の分離率も低かった。したがって， ベノミル500倍液の樹幹注入方法は, MSY-104の樹幹注入処 理と同様にナラ菌の増殖抑制効果を示すことが示唆された。 
また，2004〜2008年には，3県 8 試験地（のべ14の試験） でベノミル500倍液の樹幹注入によるナラ枯れ被害予防効果 に関する実証試験を実施した。べノミ 500 倍液の樹幹注入 において, 薬液の注入成功率が高い場合は枯死率が低くなる 傾向が認められたが，注入成功率が $60 \%$ を下回る場合は枯 死率が $100 \%$ であった．2006年の柄山試験地や 2008 年の大 宮試験地のベノミル区では枯死木は注入成功率が $60 \%$ 程度 のものは枯死した。これは, ナラ菌の接種試験からも明らか なように, 注入成功率が低くなると樹幹内にベノミル 500 倍 液が充填できずナラ菌の増殖抑制が困難になる傾向にあり, 枯死に至る可能性があると考えられた。

樹幹注入による枯損防止効果については, 心゙ノミル区は, 注入当年から 3 年目まで常に無処理区より枯死率が低かっ た. MSY-104区の一部の試験地では, 無処理区より枯死率 が高かったり, 無処理区との差が少なかったりする場合が あったことと比較すれば, 心゙ノミル区の枯損防止効果は高 く, 性能が安定していることがうかがわれた。また, Fisher の直接確率で 14 の試験ごとに検定した結果，5試験で有意差 が認められたが，その他の試験では有意差は認められなかっ た。このことは, 本試験か現地の森林で実施しているもので あり，2005年設定の弓張平試験地や 2006 年設定のキセン城 試験地をはじめとして, 無処理区においてカシナガには穿入 されたものの枯死に至った立木が予想外に少なかった試験地 があったためであると考えられた。また, 試験地として観察 に適した供試木の確保に制約があり, 各試験区の供試木が 3 本程度と少なくなり無処理区での枯死が少ない場合は有意差 がない結果になったと考えられる.

しかし，Fisherの直接確率で有意差がない場合でも，たと えば大宮試験地の 2006年と 2008年などの例では常にべノミ ル区は，無処理区よりも枯死率が低い結果であったことか ら, ベノミル 500 倍の樹幹注入は枯損防止効果が高いものと 考えられた。

このようにベノミル 500 倍液をナラ類立木へ樹幹注入する 方法はナラ類集団枯損被害の予防に有効な方法であり, さま ざまな応用の可能性があると考えられた。

樹幹注入の処理方法は様々な地域や林分, 気象条件下で実 施されることから，その結果は一様ではない可能性はある. しかし今回は最も枯死しやすいミズナラを主とするナラ類が 多い東北・中部地方において予防効果が実証された。 今後 は, ナラ菌の増殖抑制に効果がある様々な殺菌剂も含めて他 地域やシイ・カシ類といった他樹種においても利用可能な方 法かどうか検討する必要がある。

\section{要 約}

ナラ枯れの新たな予防法を開発するために, 殺菌剤べノミ ル水和剂の水希釈液を健全なミズナラに樹幹注入処理する試
験を行った。ベノミル水和剤 500 倍希橎液を樹幹注入処理し た供試木すべてに Raffaelea quercivora（ナラ菌）を多点接種 したところ，その立木は枯死せず，辺材部からのナラ菌の分 離率も対照に比べて低かった。一方, 無処理の健全木への多 点接種では試験木は枯死し, ナラ菌の分離率が高かった。ま た, 3 県 8 試験地の 14 の試験でベノミル 500 倍液の樹幹注入 処理による枯損予防効果を試験した. 処理区は無処理区に対 して常に低い枯死率であった. 処理区と無処理区の枯死率に 有意差は認められなかったが，14の試験すべてで注入当年 から 3 年後の枯死率がベノミル区で無処理区に対して低かっ たことから，被害が発生する現実林分において，べノミル 500 倍液の樹幹注入処理による枯損防止効果が高いことが示 唆された。

\section{引用文 献}

1) 伊藤進一郎, 窪野高徳, 佐橋憲生, 山田利博 : 日本林学会誌 80 , 170-175 (1998).

2) T. Kubono and S. Ito: Mycoscience 43, 255-260 (2002).

3) 斉藤正一, 柴田銃江 : 日本森林学会誌 94, 223-228 (2012).

4) 布川耕市：森林防疫 42, 210-213 (1993).

5) 斉藤正一, 市原 優, 衣浦晴生, 猪野正明：東北森林科学会誌 13, 1-4 (2008).

6) 斉藤正一, 中村人史, 三浦直美, 小野瀬浩司：森林防疫 48 , 84-94 (1999).

7）斉藤正一, 中村人史, 三浦直美：林業と薬剤 152, 1-11 (2000).

8) 斉藤正一, 中村人史, 阿部 豊, 田畑勝洋 : 山形県森林研究研修 センター研究報告 31, 15-24 (2009).

9) 斉藤正一：平成 17 年度林業薬剂等試験成績報告集，林業技術協 会, pp. 375-392, 2006.

10）小林正秀, 萩田 実: 森林防疫 52, 137-147 (2003).

11) 斉藤正一, 中村人史, 三浦直美: 林業と薬剤 166, 18-24 (2003).

12) 斉藤正一, 中村人史: 公立林業試験研究機関研究成果選集 No. 2. 独立行政法人森林総合研究所編, pp. 19-20, 2005.

13）増田信之：第 56 回日本森林学会関西支部等合同大会研究発表要 旨集, p. 65, 2005.

14) 大橋章博：第118回日本森林学会学術講演集, CD-ROM (PB076), 2007.

15）江崎功二郎：日本森林学会誌 90, 391-396 (2008).

16) 斉藤正一, 中村人史, 中江純一郎, 山本克哉: 東北森林科学会誌 11, 92-96 (2006).

17) 田畑勝洋: 第3 説 予防（松くい虫（マツ材線虫病）一沿革と最 近の研究一). 全国森林病虫獣害防除協会編, pp. 133-150, 1998.

18）斉藤正一, 中村人史, 後藤 徹：東北森林科学会誌 8, 99-101 (2003).

19）斉藤正一, 中村人史, 三浦直美, 三河孝一, 小野瀬浩司：日本林 学会誌 83, 58-61 (2001).

20) 山形県農林水産部森林課, 山形県森林研究研修センター：山形県 のナラ枯れ被害と防除, p. 22, 2011.

21）市原 優, 升屋勇人, 加賀谷悦子, 窪野高徳: 東北森林科学会誌 14, 7-11 (2009). 